\title{
Calcium Phosphate Crystal Forms in Human Jaw Bones of Changed Osteoporotic Structure
}

\author{
Srđan D. Poštić \\ Clinic for Prosthetic Dentistry, School of Dentistry, University of Belgrade, Belgrade, Serbia
}

\begin{abstract}
SUMMARY
Introduction Calcium phosphates are chemical compounds that can be found in various forms within nature, as well as in human jaws and bones. The aim of this study was to assess the structure of solid chemical compounds which form the structure of normal and osteoporotic jaw-bones.

Materials and Methods The jaw-bones taken from human cadavers were used in the study. Crystalographic forms of calcium phosphate, in the samples of human jaw-bone, were determined using X-ray diffraction technique. The experimental bone samples originated from osteoporotic jaw-bone of cadavers while control samples were taken from dentate jaw-bones of non-osteoporotic cadavers.

Results The results of this study showed that hydroxyapatite was the only phase determined in control non-osteoporotic bone samples. In experimental (osteoporotic) bone samples, the same phase was registered, as well as calcium monophosphate and hydrated calcium phosphate, registered as increments of values on $\alpha$ axis.

Conclusion Hydroxyapatite was the only compound detected in normal bone while osteoporotic bone contained others crystallographic forms of calcium phosphates.
\end{abstract}

Keywords: X-ray diffraction; microcrystals; minerals; jaw-bone

\section{INTRODUCTION}

Calcium orthophosphates are important compounds that form the structure of bone $[1,2]$. These compounds are materialized in various forms in nature, but in human bones and jaws the most important are: hydroxyapatite (HAP), with molecular formula $\mathrm{Ca}_{10}\left(\mathrm{PO}_{4}\right)_{6}(\mathrm{OH})_{2}$ (as well as: $\left.\mathrm{Ca}_{5}(\mathrm{PO} 4)_{3}(\mathrm{OH})\right)$, calcium monophosphate $(\mathrm{M})$, with formula $\mathrm{CaHPO}_{4}$, monoclinic, and hydrated calcium phosphate (B), with formula $\mathrm{CaHPO}_{4} \times 2 \mathrm{H}_{2} \mathrm{O}$, three-clinic. Besides, it has been considered that amorphous phases of calcium phosphate are most frequently registered form in nature $[3,4]$.

The coefficients of solubility (L) of calcium phosphate compounds are different at the temperature of $37^{\circ} \mathrm{C}$ and are as following: $\mathrm{L}=9.2 \times 10^{-7}$ for calcium monophosphate, $\mathrm{L}=1.87 \times 10^{-7}$ for hydrated calcium phosphate, and $\mathrm{L}=5.5 \times 10^{-118}$ for HAP [1]. However, some other sources suggest the different value for the coefficient of solubility of HAP: $\mathrm{L}=2.27 \times 10^{-58}$ at $37^{\circ} \mathrm{C}$ [5]. Hydrated calcium phosphate was obtained by mixing the solutions of $\mathrm{CaCl}_{2}$ (0.01-0.08 mol/l) and $\mathrm{NaHPO}_{4} \times \mathrm{H}_{2} \mathrm{O}(0.005-0.08 \mathrm{~mol} / \mathrm{l})$, at $\mathrm{pH}<7.1$, and the temperature of $25^{\circ} \mathrm{C}$. Additionally, at $\mathrm{pH}=7.1$ and higher, the amorphous sediment of calcium phosphate takes over and the ratio becomes $\mathrm{Ca}: \mathrm{P}=1.47$. In the mixture of the calcium hydroxide suspension and orthophosphoric acid solution, the five consecutive levels of the reaction could be indentified, previously formed HAP is transformed to hydrated calcium phosphate with the coefficient of solubility in function of the temperature of $\mathrm{L}=\mathrm{e}(8403 / \mathrm{T}+41.8-0.97 \mathrm{~T})[6]$. At $37^{\circ} \mathrm{C}$ and $\mathrm{pH}=6$, the rate of hydrated calcium phosphate formation is more than 1000 times higher than formation of HAP. In water solution with initial $\mathrm{pH}=10.8$, the temperature of $39^{\circ} \mathrm{C}$ and prolonged period of hydrolysis, hydrated calcium phosphate is transformed to HAP deficient in calcium [7]. However, extended duration of hydrolysis can be useful for transformation to normal HAP. Addition of $\mathrm{Ca}^{++}$ions accelerates the formation of HAP. That way, the amorphous calcium phosphate plays the important role in the processes of calcium phosphate formation [8]. The synthetic HAP, used in the production of artificial bone substitution, has different structure as compared to the natural HAP and it is in vivo changed by mechanical crushing and meshing of the particles. To be useful in practice, it should be processed by temperature [9]. Many chemical compounds that consist of calcium phosphates only, are used in fabrication of orthopedic and dental cements [10]. Strictly defined relationship of wet and dry particles, as well as the dimension of particles is the most important for HAP fabrication [11].

Human bone consists of different chemical compounds. The content, as well as the structure of solid phase has influence on macro-appearance and bone strength. However, some of solid compounds could be transformed into bones, as showed by stoichiometric $\mathrm{HAP}\left(\mathrm{CaO} / \mathrm{P}_{2} \mathrm{O}_{5}\right)$, HAP, calcium monophosphate and hydrated calcium phosphate $[1-4,8,11-15]$. 
The aim of this study was to assess the types of solid compounds that form the structure and composition of normal and osteoporotic human bone.

\section{MATERIALS AND METHODS}

The jaw-bones taken from cadavers were used in the study. Two groups of samples were formed (experimental and control). Experimental samples (E) were taken from osteoporotic bone while controls were the samples that originated from normal bone $(\mathrm{C})$. Each of the bone samples was carefully extracted from jaw bones using diamond bur and diamond disc. The samples of bone were extracted from two different bone layers- basal layer with the compact structure, and spongy layer from alveolar ridge, close to the mental foramen (for mandible). All of the samples had similar dimensions $(1 \times 1 \times 1 \mathrm{~cm})$ and were prismatic in shape. In order to prepare for examination, the samples were separated, isolated, cleaned and degreased in the acetone $[13,14,16-19]$. After drying and storage in vacuum conditions, samples were mechanically dusted in ahat mortar.

Roentgen diffractograms of experimental and control samples of bone were recorded in diffractometer (Crystalloflex diffractometer D-500, Siemens). Electric power of $35 \mathrm{kV}$ and $20 \mathrm{~mA}$ was used for the experiment. Powder mixture was placed in diffractometer in order to detect the phases and compounds in bone samples. Diagrams of dusts were recorded in the area of $3^{\circ}$ to $121^{\circ}$. From each of diffractograms intensities (I) and angles of $2 \Theta$ were determined. Values of angles of diffraction were calculated according to the formula: $\alpha=\lambda / 2 \sin \Theta$, where $\alpha$ is the distance of mesh of planes of Muler's index, $\lambda$ the X-ray wavelength, and $\Theta$ the angle between the $\mathrm{X}$-ray beam and parallel planes.

\section{RESULTS}

X-ray diffraction was used to analyze the mineral content of bone samples. Different parameters are shown as

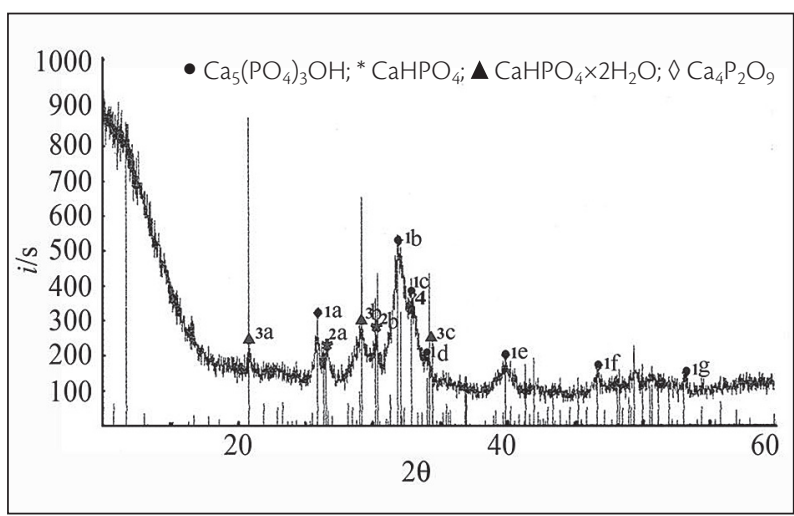

Figure 1. Diffractogram represents the inorganic constituents of microcrystals in powder made from spongy bone of experimental jaw Slika 1. Difraktogram koji predstavlja neorganski sastav mikrokristala u naprašenom uzorku spongioze eksperimentalnog uzorka kosti

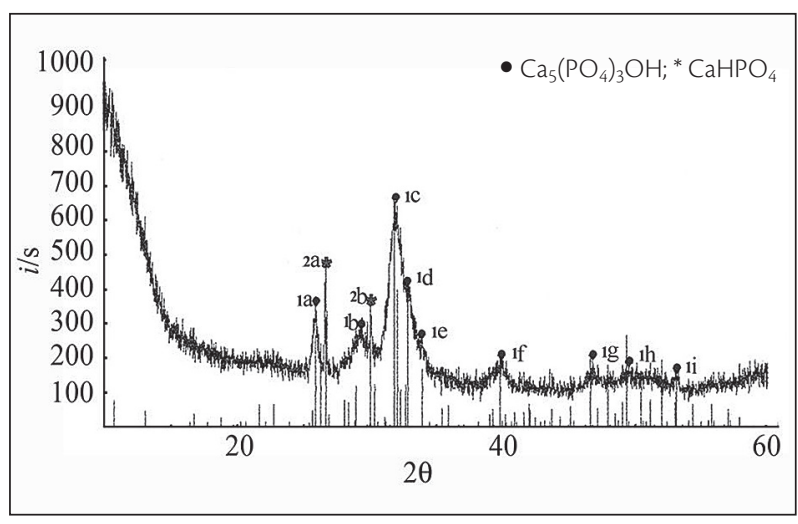

Figure 2. Diffractogram of exterior layer of experimental bone Slika 2. Difraktogram koji predstavlja neorganski sastav spoljašnjeg sloja eksperimentalnog uzorka kosti

increments of values on $\alpha$-axis while the value of c-axis remained the same.

Results of the study are shown on Table 1 and Figures 1,2 , and 3. Diffractogram of the sample $\mathrm{C}_{1}$ was identical in structure as diffractogram of the sample $\mathrm{C}_{2}$. The forms of crystals in assessed samples were determined on the basis of roentgen bands position in the spectrum $[15,16,20]$, with particular focus to their stoichiometric structure (Table 1).

Table 1. Composition of jaw-bone layers

Tabela 1. Sastav slojeva vilične kosti

\begin{tabular}{|c|c|c|c|}
\hline $\begin{array}{l}\text { Sample } \\
\text { Uzorak }\end{array}$ & $\begin{array}{l}\text { Roendgen spectrum bands* } \\
\text { Rendgenske trake i spektri* }\end{array}$ & $\begin{array}{l}\text { Crystal phase } \\
\text { Kristalna faza }\end{array}$ & $\begin{array}{l}\text { Molecular formula } \\
\text { Hemijska formula }\end{array}$ \\
\hline \multirow{4}{*}{$\mathrm{E}_{1}$} & $1 \mathrm{a}, 1 \mathrm{~b}, 1 \mathrm{c}, 1 \mathrm{~d}, 1 \mathrm{e}, 1 \mathrm{f}, 1 \mathrm{~g}$ & $\begin{array}{l}\text { Hydroxyapatite } \\
\text { Hidroksiapatit } \\
\end{array}$ & $\mathrm{Ca}_{10}\left(\mathrm{PO}_{4}\right)_{6}(\mathrm{OH})_{2}$ \\
\hline & $2 a, 2 b$ & $\begin{array}{l}\text { Calcium monophosphate } \\
\text { Kalcijum-monofosfat }\end{array}$ & $\mathrm{CaHPO}_{4}$ \\
\hline & $3 a, 3 b, 3 c$ & $\begin{array}{l}\text { Hydrated calcium phosphate } \\
\text { Hidratisani kalcijum-fosfat }\end{array}$ & $\mathrm{CaHPO}_{4} \times 2 \mathrm{H}_{2} \mathrm{O}$ \\
\hline & 4 & $\begin{array}{l}\text { Tetracalcium phosphate } \\
\text { Tetrakalcijum-fosfat }\end{array}$ & $\mathrm{Ca}_{4} \mathrm{P}_{2} \mathrm{O}_{9}$ \\
\hline \multirow{2}{*}{$E_{2}$} & $1 a, 1 b, 1 c, 1 d, 1 e, 1 f, 1 g, 1 h, 1 i$ & $\begin{array}{l}\text { Unstable phase of hydroxyapatite } \\
\text { Nestabilna faza hidroksiapatita }\end{array}$ & $\mathrm{Ca}_{10}\left(\mathrm{PO}_{4}\right)_{6} \times(\mathrm{OH})_{2}$ \\
\hline & $2 a, 2 b$ & $\begin{array}{l}\text { Calcium monophosphate } \\
\text { Kalcijum-monofosfat }\end{array}$ & $\mathrm{CaHPO}_{4}$ \\
\hline$C_{1}, C_{2}$ & $1 a, 1 b, 1 c, 1 d, 1 e, 1 f, 1 g, 1 h, 1 i$ & $\begin{array}{l}\text { Unstable phase of hydroxyapatite } \\
\text { Nestabilna faza hidroksiapatita }\end{array}$ & $\mathrm{Ca}_{10}\left(\mathrm{PO}_{4}\right)_{6} \times(\mathrm{OH})_{2}$ \\
\hline
\end{tabular}

* according to notation in the corresponding spectrum

* u skladu s nalazom odgovarajućeg spektra 


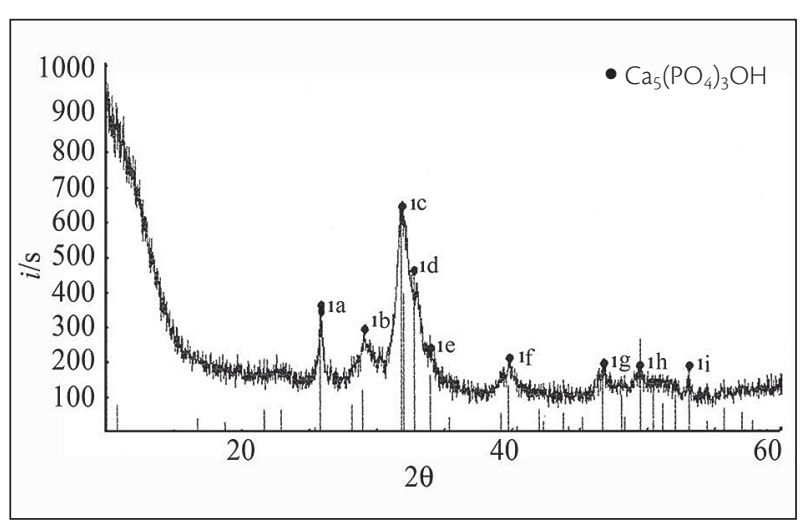

Figure 3. Diffractogram of control bone

Slika 3. Difraktogram kontrolne kosti

Obtained results showed that HAP was the dominant phase in the samples $C_{1}$ and $C_{2}$, while the bands of other phases were not present or their concentration was undetectable. In the sample $\mathrm{E}_{1}$, calcium phosphates $\mathrm{M}$ and $\mathrm{B}$ were present in equal amounts as HAP, which was confirmed by increasing values on the $\alpha$-axis, within range 20 to 40 . In the sample $\mathrm{E}_{2} \mathrm{HAP}$ and calcium monophosphate were present, with concentrated calcium monophosphate at the value 20 and higher on $\alpha$-axis.

\section{DISCUSSION}

Diffraction is reliable and proven method to determine calcium phosphates in crystals and bone structure, cements and transplants for dental, craniofacial and orthopedic application. By this method, an alignment of spectrum crystals can be visualized, as confirmed in the current study. Diffraction can show intermediary compounds also, if present in calcium's crystals in bone, with or without added biometric molecules [14, 21, 22, 23]. Very interesting finding from the current study was intermediary compound tetra calcium phosphate $\left(\mathrm{Ca}_{4} \mathrm{P}_{2} \mathrm{O}_{9}\right)$, because of its possible involvement in chemical reactions for transplant bonding to osteoporotic bone. This intermediary chemical compound was generated at the temperature of $1200^{\circ} \mathrm{C}$, when diffractogram showed apparition of tetra calcium phosphate during sintering of artificial HAP [24]. Beside the bone structure, diffraction can show crystal structure of other hard tissues (for example, enamel and dentin) [17], as well as the dimensions of crystal phase in chemical compound of calcium (HAP) [23, 25].

The results of the study indicated the existence of solid chemical compounds in osteoporotic bone. In regard to chemical analysis, osteoporosis is the process of formation some other crystal forms of calcium phosphate, calcium monophosphate and HAP, before all. Respecting the medium in which that kind of process exists, a physiologic and biochemical processes in human organism might be responsible. Also, the intensive changes in equilibrium conditions, such as $\mathrm{pH}$ of the medium, without deficiency of calcium or phosphorus in human body could be the important factor $[5,6]$. However, the ratio of calcium to phosphorous in determined compounds, as indicated in
Table 1, points to the fact that the deficiency of $\mathrm{Ca}^{++}$in physiologic medium might initiate recrystalization, i.e. from HAP where Ca:P ratio is 5:3 (in the samples $\mathrm{E}_{1}$ and $E_{2}$ ) to generate calcium monophosphate, the compound wherein the calcium to phosphorus ratio is equal (1:1). That way, the crystallography structure has been changed, as well as some other characteristics of solid phase. On the basis of that finding, it could be discussed that the reduction of calcium content in the solution or physiologic environment can influence the transition of HAP to calcium monophosphate, or hydrated calcium phosphate. Also, the formation of $\mathrm{Ca}^{++}$stable complexes with other inorganic or organic compounds could be the cause of HAP transformation into different crystal forms.

It is the fact that these kinds of studies using human samples of hard tissue are rare in national as well as international literature. The method of $\mathrm{x}$-ray diffraction is reliable for assessing crystal structure and inorganic components of bone in the analysis of oral hard tissues as well as the other tissues of human origin [14, 17].

\section{CONCLUSION}

On the basis of rentgenographic analysis, the crystallographic forms of calcium phosphates $\mathrm{M}, \mathrm{B}$, as well as HAP were detected in osteoporotic samples. In the control bone samples HAP was the only compound present.

\section{REFERENCES}

1. Wang L, Nancollas GH. Calcium orthophosphates: crystallization and dissolution. Chem Rev. 2008; 108:4628-69.

2. Arifuzzaman $S M$, Rohani S. Experimental study of brushite precipitation. J Crystal Growth. 2004; 267:624-34.

3. Christoffersen J, Christoffersen MR, Kibalczyc W, Andersen FA. A contribution to the understanding of the formation of calcium phosphates. J Crystal Growth. 1989; 94:767-77.

4. Boistelle R, Lopez-Valero I. Growth units and nucleation: the case of calcium phosphates. J Crystal Growth. 1990; 102:609-17.

5. Chen ZF, Darvell BW, Leung VWH. Hydroxyapatite solubility in simple inorganic solutions. Arch Oral Biol. 2004; 49:359-67.

6. Oliveira C, Ferreira A, Rocha F. Dicalcium phosphate dihydrate precipitation: characterization and crystal growth. Chemical Engineering Research and Design. 2007; 85:1655-61.

7. Štulajterová R, Medvecký L. Effect of calcium ions on transformation brushite to hydroxyapatite in aqueous solutions. Colloids and Surfaces A: Physicochemical and Engineering Aspects. 2008; 316:104-9.

8. Tenhuisen KS, Brown PW. The kinetics of calcium deficient and stoichiometric hydroxyapatite formation from $\mathrm{CaHPO} 4 \times 2 \mathrm{H} 2 \mathrm{O}$ and Ca4(PO4)2O. J Mat Science Mater in Medicine. 1996; 7:309-16.

9. Nakano T, Umakoshi Y, Tokumura A. Variation in crystallinity of hydroxyapatite and the related calcium phosphates by mechanical grinding and subsequent heat treatment. Metallurgical and Materials Transactions A. 2002; 33:521-8.

10. Jalota S, Tas AC, Bhaduri SB. Synthesis of HA-seeded TTCP (Ca4(PO4)2O) powders at $1230^{\circ} \mathrm{C}$ from $\mathrm{Ca}(\mathrm{CH} 3 \mathrm{COO}) 2 \times \mathrm{H} 2 \mathrm{O}$ and NH4H2PO4. J Amer Ceram Soc. 2005; 88:3353-60.

11. Pontier C, Viana M, Champion E, Bernache-Assollant D, Chulia D. About the use of stoichiometric hydroxyapatite in compression incidence of manufacturing process on compressibility. Eur J Pharm Biopharm. 2001; 51:249-57.

12. Boyde A, Kingsmill VJ. Age changes in bone. Gerodontology. 1998; 15:25-34. 
13. Poštić SD. An analysis of osteoporotic changes in mandible, and it's clinical significance [doctoral dissertation]. Belgrade: Faculty of Stomatology, University of Belgrade; 1998.

14. Poštić SD, Marković V, Veselinović D, Mirjanić M, Zec S. Physicalchemic characterisation of osteoporotic bone. Proceedings of 37th Annual Meeting of IADR/CED, Rome, Italy, 5-8 September 2001; Rome: IADR/CED; 2002. p.284.

15. Zhao G. Interaction of surface energy and microarchitecture in determining cell and tissue response to biomaterials; 2007. Available from: http://smartech.gatech.edu/bitstream/handle/1853/24656/ Zhao_Ge_200708_PhD.pdf?sequence=1

16. Briggs D, Brady J, Newton B. Scanning electron microscopy and X-ray microanalysis; 2000. Available from: http://www.science.smith.edu/ departments/SEM/Manual99.pdf

17. Tihaček Lj. Possibilities of binding organic molecules within the enamel crystal structure. Stomatološki glasnik Srbije. 1999; 46:83-7.

18. Poštić SD. Therapy and prosthetic rehabilitation of edentulous ridges of osteoporotic jaws. Beograd: Zadužbina Andrejević; 2010.

19. Boyde A, Jones SJ. Scanning electron microscopy of bone: instrument, specimen, and issues. Microsc Res Tech. 1996; 33:92-120.

20. Smith DK, Jenkins R. The powder diffraction file: past, present, and future. I Res Natl Inst Stand Technol. 1996; 101:259-71.
21. Sillen A, Morris A. Diagenesis of bone from Border Cave: implications for the age of the Border Cave hominids. Journal of Human Evolution. 1996; 31:499-506.

22. Abe S, Fuji Y, Kusuhara A, Yamatoya E, Ishida T, Akasaka T, et al. Controlled calcification using biomimetic macromolecules [abstract]. ISACB abstracts. International Symposium on Apatite and Correlative Biomaterials, Cairns Convention Centre, 10-12 December, 2010; p.54-55.

23. Xu HHK, Zhao L,Weir MD. Stem cell-calcium phosphate constructs for bone engineering. J Dent Res. 2010; 89:1482-8.

24. Mezahi FZ, Oudadesse H, Harabi A, Le Gal Y, Cathelineau G. Sintering effects on physico chemical properties and on kinetics of bioactivity of natural and synthetic hydroxyapatite [abstract]. ISACB abstracts. International Symposium on Apatite and Correlative Biomaterials. Cairns Convention Centre, 10-12 December, 2010; p.75.

25. Hile DD, Sonis ST, Doherty SA, Tian XY, Zhang Q, Jee WSS, et al. Dimensional stability of the alveolar bioabsorbable bone graft substitute a radiographic and histomorphometric study in rats. J Oral Implantol. 2005; 31:68-76.

Received: 10/09/2010 • Accepted: 16/02/2011 


\title{
Oblici kalcijum-fosfata u kosti ljudskih vilica promenjene strukture usled osteoporoze
}

\author{
Srđan D. Poštić \\ Klinika za stomatološku protetiku, Stomatološki fakultet, Univerzitet u Beogradu, Beograd, Srbija
}

\begin{abstract}
KRATAK SADRŽAJ
Uvod Jedinjenja kalcijum-fosfata se u prirodi nalaze u različitim oblicima, a mogu se naći i u vilicama i kostima kod ljudi. Cilj ovog rada je bio da se proveri sastav čvrstih hemijskih jedinjenja koja čine strukturu normalne i kosti vilica zahvaćene osteoporozom. Materijal i metode rada Kao materijal u istraživanju korišćene su vilice kadavera. Kristalografski oblici kalcijum-fosfata u kostima vilica određeni su metodom difrakcije rendgenskim zracima. Eksperimentalni uzorci kostiju su izdvojeni iz bezubih osteoporoznih vilica, a kontrolni uzorci iz ozubljenih vilica bez osteoporoze.

Rezultati Dobijeni rezultati su pokazali da je hidroksiapatit jedina kristalna faza u kontrolnim uzorcima vilica. U uzorcima vilica s osteoporozom, pored navedene faze, uočeni su i kalcijum-monofosfat i hidratisani kalcijum-fosfat kod povećanja vrednosti na alfa osi.

Zaključak Kod normalne kosti zastupljen je samo hidroksiapatit, dok se kod kosti zahvaćene osteoporozom javljaju i drugi kristalografski oblici kalcijum-fosfata.
\end{abstract}

Ključne reči: difrakcija; mikrokristali; mineralni sastav kosti; vilica

\section{UVOD}

Kalcijum-ortofosfati su značajna jedinjenja koja učestvuju u formiranju strukture kosti $[1,2]$. Ova jedinjenja se u prirodi nalaze u različitim oblicima, ali su u kostima i vilicama ljudi najvažniji hidroksiapatit (HAP), čija je hemijska formula $\mathrm{Ca}_{10}\left(\mathrm{PO}_{4}\right)_{6}(\mathrm{OH})_{2}$ (negde i: $\mathrm{Ca}_{5}\left(\mathrm{PO}_{4}\right)_{3}(\mathrm{OH})$ ), kalcijum-monofosfat $(\mathrm{M})$, čija je hemijska formula $\mathrm{CaHPO}_{4}$, i hidratisani kalcijum-fosfat (B), odnosno kalcijum poluhidrat, čija je hemijska formula $\mathrm{CaHPO}_{4} \times 2 \mathrm{H}_{2} \mathrm{O}$. Smatra se da je amorfni oblik kalcijum-fosfata i najčešći hemijski oblik u prirodi $[3,4]$.

Koeficijent rastvorljivosti (L) za jedinjenja kalcijum-fosfata je različit na temperaturi od $37^{\circ} \mathrm{C}: 9,2 \times 10^{-7}$ za kalcijum-mo-

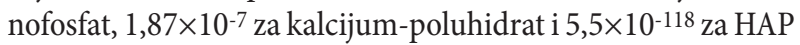
[1]. Međutim, prema nekim naučnim izvorima, koeficijent rastvorljivosti HAP je drugačiji od prvobitno utvrđenog i iznosi $2,27 \times 10^{-58}$ pri temperaturi od $37^{\circ} \mathrm{C}$ [5]. Hidratisani kalcijumfosfat je dobijen mešanjem rastvora $\mathrm{CaCl}_{2}(0,01-0,08 \mathrm{~mol} / \mathrm{l}) \mathrm{i}$ $\mathrm{NaHPO}_{4} \times \mathrm{H}_{2} \mathrm{O}(0,005-0,08 \mathrm{~mol} / \mathrm{l})$ pri vrednosti $\mathrm{pH}$ manjoj od 7,1 i temperaturi od $25^{\circ} \mathrm{C}$. Ipak, pri vrednosti $\mathrm{pH}$ od 7,1 i većim, amorfni sediment kalcijum-fosfata počinje da preovladava, pri čemu se odnos kalcijuma i fosfora menja u Ca:P=1,47. U složenoj suspenziji kalcijum-hidroksida s rastvorom ortofosforne kiseline može se javiti pet nivoa reakcije, pri čemu se prethodno stvoreni HAP transformiše u hidrat kalcijumfosfata $s$ koeficijentom rastvorljivosti u funkciji temperature od $\mathrm{L}=\mathrm{e}(8403 / \mathrm{T}+41,8-0,97 \mathrm{~T})[6]$. Pri temperaturi od $37^{\circ} \mathrm{C} \mathrm{i}$ vrednosti $\mathrm{pH}$ od 6 , stepen formiranja hidrata kalcijum-fosfata je više od hiljadu puta veći u odnosu na jedinjenje HAP. U vodenom rastvoru s početnom vrednošću $\mathrm{pH}$ od 10,8 i pri temperaturi od $39^{\circ} \mathrm{C}$, posle produženog perioda hidrolize, hidrat kalcijum-fosfata se transformiše u HAP u kojem je kalcijum deficitaran [7]. Međutim, produženo trajanje procesa hidrolize može uticati na stvaranje HAP u kojem je kalcijum pravilno zastupljen. Dodatak kalcijuma $\left(\mathrm{Ca}^{++}\right.$jona) ubrzava stvaranje HAP. Na ovaj način, amorfni kalcijum-fosfat ima važnu ulogu u procesu stvaranja kalcijum-fosfata [8]. Sintetisani HAP, koji se koristi za stvaranje veštačkih zamenika kosti, drugačije je strukture od prirodnog HAP, koji je u uslovima in vivo izmenjen zbog mehaničkih delovanja i rasejavanja partikula i koji bi se, zbog primene, morao dodatno termički obraditi [9]. Mnoga hemijska jedinjenja koja se sastoje uglavnom od kalcijumfosfata primenjuju se u proizvodnji veštačkih cementa u ortopedskoj hirurgiji i industriji dentalnih cementa [10]. U proizvodnji HAP veoma je značajan tačno utvrđen odnos vlažnih i suvih čestica, kao i dimenzija čestica [11].

Ljudska kost se sastoji od različitih hemijskih jedinjenja. Sadržaj i struktura čvrste faze utiču na makroprikaz i jačinu kosti. Ipak, pojedina jedinjenja se mogu izmeniti u kosti, na šta ukazuju opisi stoihiometrijskog $\mathrm{HAP}\left(\mathrm{CaO} / \mathrm{P}_{2} \mathrm{O}_{5}\right)$, HAP, kalcijum-monofosfata i hidratisanog kalcijum-fosfata [1-4, 8, 11-15].

Cilj ovog rada je bio da se utvrde čvrsta hemijska jedinjenja koja čine strukturu i ulaze u sastav normalne i kosti ljudskih vilica zahvaćene osteoporozom.

\section{MATERIJAL I METODE RADA}

Kao materijal u istraživanju korišćene su vilične kosti kadavera. Eksperiment je vršen na dve grupe uzoraka. Eksperimentalni uzorci (E) su izdvojeni iz kosti čija je struktura promenjena usled osteoporoze, dok su uzorci iz normalne kosti (C) činili kontrolnu grupu. Svaki uzorak je pomoću dijamantskog borera i dijamantskog diska pažljivo izvađen iz mase kosti vilica kadavera. Uzorci su ekstrahovani iz dva različita sloja vilica: bazalnog sloja kosti, kompaktne građe, i sunđerastog sloja u alveolarnom nastavku, u blizini foramena mentale za donju vilicu. Svi uzorci su bili slične veličine $(1 \times 1 \times 1 \mathrm{~cm})$ i prizmatičnog oblika. Uzorci su razdvojeni, izolovani, očišćeni i razmašćeni u acetonu radi pripreme za fiksaciju i ispitivanje [13, 14, 16-19]. Posle sušenja i čuvanja u vakuumu, uzorci su mehanički naprašeni $u$ ahatnom avanu.

Rendgenski difraktogrami eksperimentalnih i kontrolnih uzoraka snimljeni su u difraktometru (Crystalloflex difractometer D-500, Siemens). Radni napon rendgenske cevi bio je 35 $\mathrm{kV}$, a jačina struje $20 \mathrm{~mA}$. Naprašena supstanca iz uzoraka je 
postavljena u difraktometru, kako bi se ustanovili faze i jedinjenja iz uzoraka kosti. Dijagrami praha su snimljeni u području od $3^{\circ}$ do $121^{\circ}$. Sa svakog difraktograma su određeni intenziteti (I) i uglovi $2 \Theta$. Vrednosti uglova difrakcije su izmereni prema jednačini $\alpha=\lambda / 2 \sin \Theta$, gde je $\alpha$ udaljenost mrežnih ravni Milerovih indeksa, $\lambda$ talasna dužina rendgenskog zračenja, a $\Theta$ ugao koji zaklapaju rendgenski zrak i paralelne ravni.

\section{REZULTATI}

Difrakcijom rendgenskim zracima izvršena je analiza mineralnog sadržaja iz uzoraka kosti. Različitost parametara je predstavljena ustanovljenim povećanjima vrednosti $\alpha$-ose, dok se vrednost c-ose nije menjala.

Rezultati istraživanja su prikazani na tabeli 1 i slikama 1, 2 i 3. Difraktogram kontrolnog uzorka $\mathrm{C}_{1}$ je bio istovetan zabeleženom difraktogramu kontrolnog uzorka $\mathrm{C}_{2}$. Forme kristala iz ispitivanih uzoraka su određene na osnovu položaja rendgenskih traka u spektrumu $[15,16,20]$ s posebnim fokusom na njihovu stoihiometrijsku strukturu (Tabela 1).

Dobijeni rezultati su pokazali da je HAP dominantna faza u uzorcima $\mathrm{C}_{1} \mathrm{i}_{2}$, uzimajući u obzir činjenicu da trake nekih drugih faza nisu bile zastupljene ili je koncentracija ovih faza bila ispod nivoa detekcije. $\mathrm{U}$ uzorku $\mathrm{E}_{1}$ jedinjenja kalcijummonofosfat i hidratisani kalcijum-fosfat bila su podjednako zastupljena, kao i HAP, što je utvrđeno povećanjem vrednosti na a-osi, posebno u rasponu od 20 do 40 . $\mathrm{U}$ uzorku $\mathrm{E}_{2}$ ustanovljeni su HAP i kalcijum-monofosfat, a kalcijum-monofosfat bio je zastupljen već posle vrednosti 20 na $\alpha$-osi.

\section{DISKUSIJA}

Difrakcija je proverena i pouzdana metoda za utvrđivanje kalcijum-fosfata u kristalima i sastavu kosti, cementa i transplantatima za dentalnu, kraniofacijalnu i ortopedsku primenu. Ovom metodom moguće je prikazati utvrđen redosled kristala u spektru, što je potvrđeno i u ovom istraživanju. Difrakcija prikazuje i intermedijarna jedinjenja, ukoliko postoje u kalcijumovim kristalima u kosti, sa dodatkom biometrijskih molekula ili bez njih [14, 21, 22, 23]. Stoga je u ovom istraživanju posebno zanimljiv nalaz intermedijarnog jedinjenja tetrakalcijum-fosfata $\left(\mathrm{Ca}_{4} \mathrm{P}_{2} \mathrm{O}_{9}\right)$, na koje bi trebalo obratiti pažnju zbog mogućeg učešća u hemijskim reakcijama vezivanja transplantata za kost koja je zahvaćena osteoporozom. Ovo jedinjenje je hemijski stvoreno pri temperaturi od $1200^{\circ} \mathrm{C}$, kada difraktogram prikazuje aparaciju tetrakalcijum-fosfata pri sinterovanju veštačkog HAP [24]. Osim utvrđivanja sastava kosti, difrakcija pokazuje kristalni sastav i drugih čvrstih tkiva (npr. gleđi i dentina zuba) [17], kao i dimenzije kristalne faze u jedinjenjima kalcijuma (HAP) [23, 25], što nije bio cilj ovoga istraživanja.

Rezultati istraživanja su ukazali na različit sastav čvrstih hemijskih jedinjenja u osteoporoznoj kosti. S aspekta hemijske analize, osteoporoza je proces stvaranja kristala različitih po strukturi od kalcijum-fosfata, odnosno od kalcijum-monofosfata i HAP. Uzimajući u obzir medijum u okviru kojeg se ovaj proces razvija, fiziološki i biohemijski procesi bi mogli biti najodgovorniji za ovakva stanja. Osim toga, značajan faktor bi mogle biti i intenzivne promene $\mathrm{pH}$ vrednosti u medijumu, bez nedostatka kalcijuma i fosfora u ljudskom organizmu [5, 6]. Međutim, odnos kalcijuma i fosfora u hemijskim jedinjenjima, kao što je prikazano u tabeli 1 , ukazuje na činjenicu da nedostatak kalcijuma u fiziološkom medijumu može inicirati ponovnu kristalizaciju; tačnije rečeno, od HAP, u kojem je odnos kalcijuma i fosfora 5:3 (i u uzorku $E_{1}$ i u uzorku $E_{2}$ ), može usloviti dominaciju kalcijum-monofosfata, jedinjenja u kojem je odnos kalcijuma i fosfora jednak (1:1). Na ovaj način dolazi do izmena kristalografske strukture, ali i čvrste faze jedinjenja u medijumu. Ovakvi nalazi upućuju na to da smanjenje sadržaja kalcijuma u rastvoru ili fiziološkoj sredini može dovesti do prelaska HAP u kalcijum-monofosfat ili hidratisani kalcijum-fosfat. Pored toga, stvaranje stabilnih kompleksa kalcijuma $\mathrm{Ca}^{++}$sa drugim neorganskim i organskim komponentama moglo bi biti uzrok transformacije HAP u drugačije kristalne forme.

Činjenica je da istraživanja ovakve vrste na humanim uzorcima čvrstog koštanog tkiva nisu brojna ni u domaćoj, niti u stranoj literaturi. Metoda difrakcije rendgenskim zracima je sasvim pouzdana u ispitivanju kristalnog sastava i neorganske strukture kosti u analizi čvrstih oralnih i drugih tkiva humanog porekla, odnosno supstanci za primenu kod ljudi [14, 17].

\section{ZAKLJUČAK}

Na osnovu rendgenografskih analiza utvrđeno je postojanje kristalografskih formi kalcijum-monofosfata, hidratisanog kalcijum-fosfata i HAP u eksperimentalnim uzorcima kosti zahvaćene osteoporozom. U uzorcima normalne kosti, bez osteoporoze, zastupljen je bio samo HAP. 